\title{
Meleke olarak belâgat
}

Ali TÜLÜ1

APA: Tülü, A. (2020). Meleke olarak belâgat. RumeliDE Dil ve Edebiyat Araştırmaları Dergisi, (20), 526-537. DOI: 10.2900o/rumelide.792168.

\section{$\ddot{\mathbf{O} z}$}

İnsanoğlunun varoluşundan itibaren en önemli özelliklerinden biri kendini ifade edebilme(beyan) ve karşısındakini anlamayı isteme(istibâne) olgusudur. İnsanoğlunun kendini ifade etme biçimlerinden en yaygın olanı da sözlü ifade etme biçimidir. Sözlü ifade biçiminde, maksadı, muhatabın durumu ve o halin gereğine göre en düzgün ve en etkili bir şekilde ifade etmek amaç olmuştur. Arapça konuşan toplumlarda da Câhiliye döneminden itibaren güzel ve etkili söz söyleme tüm toplumun önem verdiği, kendisi için çabaladığı bir amaçtır. Bu amaçla söylenilen sözler kimi zaman bizzat söyleyen tarafından kimi zaman da muhataplar veya üçüncü şahıslar tarafından değerlendirmeye tabi tutulmuşlar hatta aynı anlamı ifade eden sözlü beyanlar arasında karşılaştırmalar yapılmıştır. Bu değerlendirmeler ve karşılaştırmalar ilk dönemlerde sözlü beyanları değerlendiren/karşlaştırma yapanların melekelerine göre birkaç temel esasa göre ve genel değerlendirmeler şeklinde olmuştur. Daha sonra bu değerlendirmelerin rivayetleri yazılı metinlere geçmeye başlamış ve farklı kültürden de etkilenmeler sonucunda değerlendirme esasları ayrıntılı bir şekilde tespit edilerek müstakil bir ilim halini almıştır. Bu ilim, Arapça dil ilimleri içerisinde müstakil bir ilim halini en son alan belâgat ilmidir. Belâgat ilminin yazılı ve ayrıntılı esasları belirlenmeden önceki hali, "meleke olarak belâgat” başlı̆̆ı altında ele alınmaktadır. Bu çalışmada "meleke olarak belâgat”ın, özellikle ilk dönem kaynakları esas alınarak, incelemesi hedeflenmiştir.

Anahtar kelimeler: Beyân, Belâgat, Câhiliye dönemi, Edebi eleştiri, Arap dili

\section{Rhetoric as faction}

\begin{abstract}
One of the most important features of mankind since its existence is the phenomenon of selfexpression (bayân) and wanting to understand (istibâne). The most common form of human selfexpression is verbal expression. In the form of verbal expression, it was the aim to express the purpose in the most correct and effective way according to the condition of the respondent and the requirement of the situation. In Arabic speaking societies, it is an aim that the whole society gives importance and strives for, since the time of Jahiliyya. The words spoken for this purpose sometimes were evaluated by the person who said it, sometimes by the respondents or third parties, and even comparisons were made between verbal statements with the same meaning. These evaluations and comparisons were based on a few basic principles and general evaluations according to the natural faculty of those who evaluated / compared oral statements. Later, the narrations of these evaluations started to be written in texts and as a result of being affected by different cultures, the principles of assessment were determined in detail and became a detached science. This is the science of rhetoric, which has taken the form of a detached knowledge latest among the Arabic language sciences. The written and detailed principles of the science of rhetoric are addressed under the heading "rhetoric
\end{abstract}

Dr. Öğr. Üyesi, İstanbul Șehir Üniversitesi, İslami ̇̇limler Fakültesi, Temel İslam Bilimleri ABD (İstanbul, Türkiye), alitulu32@gmail.com, ORCID ID: 00oo-00o2-3245-2744 [Makale kaylt tarihi: 15.06.2020-kabul tarihi: 19.06.2020; DOI: $10.29000 /$ rumelide.792168] 
as natural faculty". In this study, it is aimed to examine "rhetoric as natural faculty" especially based on the sources of the first period.

Keywords: Beyân, rhetoric, The Age of Jahiliyya, literary criticism, Arabic language

\section{Giriş}

Kimileri belâgatın bir ilim olarak ortaya çıkışını Sîbeveyhi’ye (ö. 180/796) kadar götürmüş, (Merâgî, 1993, s. 7; Muhammed, 1999, s. 9) kimileri de bu ilmin kurucusunun Câhiz (ö. 255/869) olduğunu söylemişlerdir. (Atîk, 2005, s. 51) Ancak genel kabul belâgat ilminin, dil ilimleri içerisinde bağımsızlı̆̆ına en son kavuşan ilim olduğu yönündedir. Buna göre İbnü’l-Mu‘tez (ö. 296/908), belâgatın özellikle bedî‘ kısmen de beyan ilmine dair telif ettiği "el-Bedî" adlı eseriyle bu alanda eser veren ilk kişi olarak kabul edilmektedir. Ancak "Delâilü'l-i'caz ve Esrâru'l-belâga" adındaki eserleriyle belâgat ilminin bütün konularına işaret etmesi sebebiyle Abdülkâhir el-Cürcânî (ö. 471/1078-79) bu ilmin bağımsız bir ilme dönüşmesinde en büyük payın sahibidir. Abdülkâhir el-Cürcânî'den önce ve sonra birçok alimin katkıda bulunduğu bu ilim; meânî, beyân, bedî‘ adındaki bölümleriyle son şeklini Sekkâkî (ö. 626/1229) ve Kazvînî (ö. 739/1338) eliyle almıştır. (Arslan, 2019, s. 597) Bu da gösteriyor ki belâgatın kitaplarda müstakil bir ilim olarak yer alması uzun sayllabilecek bir dönemi kapsamaktadır. O halde şu soru anlamlı hale gelmektedir. Bağımsız bir ilim olarak kitaplarda yer bulması birkaç asrı bulan bu ilim yazılı kurallara tabi olmadığı dönemde yok muydu? Bu ilimde istişhad olarak Kur'ân âyetleri, Hadis-i şerifler ve kadim Arap şiirinin kullanılması önceden de bu ilmin varlığının en büyük delilidir. Bu sebepledir ki belâgat tarihi üzerine çalışma yapanlar "belâgat" kavramını biri meleke diğeri de ilim olmak üzere iki bölümde ele almaktadırlar.

Belâgatın bir ilim olarak ortaya çıkış sürecini ele alan gerek Arapça gerekse Türkçe olarak birçok çalışmanın varlığı bilinmektedir. Ancak yazılı kuralları olmayan belâgatın bir meleke olarak ele alındığı müstakil bir çalışmayı özellikle Türkçe kaynaklarda tespit edemedik. Bu sebeple çalışmamızda bir meleke olarak belâgat kavramı ele alınmaya çalışılacaktır.

İlimler yazıya dökülmeden önce uzun bir süre sözlü olarak nesiller arası geçişle tekâmül sürecine devam ederler. Kimi zaman bu süreçte birkaç ilim bir çatı altında değerlendirilir ve her birinin müstakil bir ilme dönüşmesi daha sonraki dönemlerde olur. $\mathrm{Bu}$ süreçte ilimler içerisinde var olan konular belirginleşmeye, ayrışmaya hatta bir kısmı da ön plana çıkmaya başlar. Bazen kimi ilimler bu öne çıkan konularla ifade edilir veya bu konulardan ibaret sanılabilir. Daha sonra söz konusu ilimlerle ilgili ilk yazılı metinlerde hem ilimlerin kendileri hem de konu ve kavramları için isim ve ıstılahlar ortaya çıkar. Yukarıdaki anlatıma uygun gelişme gösteren ilimlerden biri de belâgat ilmidir. Bu ilim, cahiliye döneminden itibaren bir meleke olarak, sözlü bir şekilde nesilden nesle aktarıldı.

\section{A. Arap dilinin özellikleri ve Arap edebiyatında dil birliği meselesi}

\section{Arap dilinin özellikleri}

Beyan çeşitlerinden biri olan sözlü beyan, bütün diller için geçerli olmakla beraber olmakla birlikte Arap dilinin bu hususta farklılı̆̆ ve diğer dillere üstünlüğü bilinmektedir. Nitekim kaynaklarda, Arapların diğer milletlerden daha fasih konuştuğu, dillerinin daha geniş olduğu, bu dilin lafızlarının birçok farklı anlamı kapsadığı, kelamın meydana geliş şekillerinin çeşitliliği ve kullanılan deyim ve atasözlerinin (meseller) fazlalığı dile getirilmektedir. Ayrıca açık seçik/bedîhî konuşmanın Araplara mahsus bir özellik olduğu ve cümleler arasında münasebet kurarak doğaçlama/irticâlî konuşmanın da Araplara özgü olduğu dile getirilir. (Câhiz, 2018, c. 1, ss. 222-223) 
Arapların sıradan konuşmaları bile doğaçlama/irticâlî olup, net ve sorunsuz anlaşılabilme kapasitesine sahiptir. Bu özellik Araplar için herhangi bir düşüncenin ya da ortak bir çalışmanın ürünü olmayıp, ilham yoluyla oluşmuş gibidir. (Câhiz, 2018, c. 3, ss. 425,-426, 607, 620) Ayrıca Arapların cahiliye döneminde şiir ve hitabet yarışmaları düzenleyip bu vesileyle dil ve edebiyatı öne çıkarmaları ve bu yarışmalarda kazananları ödüllendirmeleri de onların dil ve edebiyata verdikleri önemi göstermektedir. (Mübârek, 2001, s.25-26) Kur'ân-ı Kerim’in eşsiz belâgatıyla onlara meydan okumuş olması ve onların da bu meydan okumanın muhatabı olmaları, Kur'ân-ı Kerim’in kendisiyle indiği dilin inceliklerini, sırlarını, ifade şekillerini ve edebiyatını bilmelerini gerektirmektedir. Hatta bu bilme "Kur'ân ile kendilerine meydan okunmasına ve işittikleri bu kelamı okuyanın da Allah Teâlâ'nın peygamberi olduğuna şehadet etmelerinin istenmesine" imkân verecek ölçüde olmalıdır (Şakir, 2002, ss. 164-165, 173-174; a.g.m., t.y., ss. 94-95, 104, 111-112; Tülü, 2016, s. 234)

İbn Kuteybe de Arap dilinin diğer dillerden üstün olduğunu savunanlardandır. O, Arap dilini diğer dillerle karşılaştırır ve Arap dilinde var olan ifade çeşitliliğinin diğer dillerde olmadığını söyler. Arap dilinin bu özelliğinin ona Allah tarafından verildiğini, bu yüzden Kur’an-ı Kerim’in diğer dillere tercüme edilemeyeceğini savunur. (İbn Kuteybe, ty. ss. 17-22) Ayrıca Arapça'ya özgü olan irab konusunun bu dile katkılarını örneklerle izah eden İbn Kuteybe, bu dilin bir başka özelliğine daha dikkat çekerek, harf ve hareke değişimiyle kelimelerin yakın anlamları arasındaki değişimleri anlatır. (İbn Kuteybe, ty., ss.1820) Ona göre Arap hatipler kimi zaman kinaye yapar, bazen de maksatlarını açıça/sarahaten ifade ederler, bazen de sadece zeki ve anlayışı güçlü olanlar anlasın diye manayı kapalı bırakırlar. Onlar bazen kısa ve özlü cümleler kurarlarken bazen de maksatlarını tam olarak anlatabilmek için kelamı uzatırlar. Yine onlar ifadelerinin tamamını edebi sanatlarla süslemezken diğer yandan edebi sanatları kullanmaktan tamamen de kaçınmazlar ikisi arasında orta, güzel bir yol tutarlar ve bulundukları makama, muhatap olan topluluğa ve duruma göre konuşurlardı. (İbn Kuteybe, ty., ss. 17, 58) Hülâsa Kur'ân'ı Kerim'in kendisiyle nazil olduğu dil kendi doğası itibarı ile beşer kelamı ile Allah kelamı arasındaki bu devasa farkı yüklenebilecek, taşıyabilecek özelliklere ve ifade gücüne sahip olmalıdır. Yani bu dil hem beşer kelamının en üst zirvesini ifade edebilmeli, hem de ondan her yönüyle farklı olan ilâhi kelamın, beşerin tüm yeteneklerini ve kudretini aciz bırakabilmesine uygun olmalıdır. (Şakir, 2002, s. 164; a.g.m., t.y., s. 111; Tülü, 2016, s. 234)

\section{Edebi dil birliği}

Arapçanın diğer dillere üstünlüğünü savunanlar, Araplardaki kabile dilleri ve lehçelerinin farklı farklı oluşu sebebiyle gelebilecek itirazları defetmek için, günümüze intikal eden Arap edebiyatının, kabilelerin dili ya da lehçeleri olmayı üzerinde ittifak edilen dil üzerinden oluşmuş Arap edebiyatı olduğunu savunmuşlardır. Nitekim Câhiliye dönemi şairleri, kelime hazinesi ve ifade şekilleri oldukça gelişmiş zengin bir dile sahiptiler. Onlar da bu dili en güzel şekilde kullanıyorlar ve sanatlarını bu dil aracılı̆̆ ile icra ediyorlardı. (Hüseyin, t.y., ss.91-93; Dayf, el-'Asru'l-câhilî, ss.418-419; Özdemir, 2007, s.16; Tülü, 2016, s. 225) O dönemin edipleri arasında istisnaları hissedilebilecek tarzda Kur'an-1 Kerim’in nüzulünden önce panayırlarda müşterek bir edebî üst dil gelişmişti. Nitekim Kur’an'ın meydan okuması da tüm Arap kabilelerine karşıydı. Bu da Kur’an-ı Kerim’in nüzulünden önce bir dil birliği olduğunu göstermektedir. (Afgânî, 1974, ss. 277-290; Mübârek, 2001, ss.25-26) Bu dil, kabile lehçelerinin üzerinde bir dil olup her kabileden şairler bu müşterek edebî dille şiirlerini yazmışlardır. Panayırlarda ve farklı münasebetlerle bir araya geldiklerinde kendi aralarında yarışan şairlerden bu dili bırakıp kendi kabile lehçeleriyle şiir yazmasını beklemek doğru değildir. Klasik Arapça'nın dili ve sistemleştirilen kâideleri de bu müşterek edebî dil üzerine kuruludur. (Hüseyin, t.y., ss.91-93; Dayf, el'Asru'l-câhilî, ss.418-419; Özdemir, 2007, s.16; Tülü, 2016, s. 225) Bugün kabul edilen görüşe göre bu müşterek dilin kaynağı başka bir deyişle bu dile esas unsurlarını veren lehçeler, Kays, Temim, Hüzeyl, Tayy ve Kureyş kabilelerinin lehçeleridir. (Çetin, 2011, s. 38; Tülü, 2016, s. 225) Farklı lehçelerde şiir irad eden şairler de vardır ki bunların şiirlerinin bir kısmı, ilk dönem âlimleri tarafından tenkide tabi 
tutulmuş ve lügat, gramer ve nevadire ait eserlerde zikredilmiştir. (Râfiî, 1997, s.39; Çetin, 2011, s. 39; Tülü, 2016, s. 225)

\section{B. Belâgatla ilgili kavramlar}

\section{Beyan kavramı}

Belâgat, Araplara mahsus olmayıp bütün milletlerde var olan bir olgudur. Dolayısıyla bir meleke olarak belâgatın tarihi insanlık tarihi kadar eskidir. Nitekim Kur'ân-ı Kerim'de "Allah insana beyânı öğretti" (Rahmân 55/4) âyeti de buna işaret etmektedir. Bu âyette ifadesini bulan beyan kavramı, genel olarak insanın kendini ifade edebilme yeteneği olarak anlaşılsa da müstakil bir ilme dönüşmeden önce belâgatın meselelerinin de genellikle bu kavramla ifade edildiği bir gerçektir. O halde burada kısaca beyan kavramı üzerinde durulacaktır.

"Beyan”, mana üzerindeki perdeyi açan ve aklın üzerindeki örtüyü kaldıran, böylelikle muhatabın anlam ve maksada ulaşmasını sağlayan kapsamlı bir kavramdır. Beyanda önemli olan konuşanın maksadını anlatabilmesi, dinleyenin de bunu anlayabilmesidir. Bunun hangi yöntemle gerçekleştĭgi önemli değildir. (Câhiz, 2018, c. 1, s. 56) Tanımdan da anlaşlacağı üzere beyan kısaca "kişinin kendisini ifade edebilme yeteneği” olup, sadece lafızlarla gerçekleşen bir şey değildir. Zira; lafız, işaret, akd, hat ve hal olmak üzere birkaç çeşit beyan vardır. Bu anlamdaki beyanın zıddı olarak "kişinin kendini ifade edememesi” anlamına gelen "ع/'اعي" kelimesi kullanılmaktadır. (Câhiz, 2018, c. 1, s. 57; Bâkıllânî, 1997, ss. 274-275) O halde bu anlamıyla beyan sadece belâgat ilmiyle sınırlı olmayıp, "kişinin kendini ifade edebilmesi" anlamında daha kapsamlıdır.

İlk dönem Arap edebiyatçıları, beyan çeşitlerinden belâgata temel teşkil eden sözlü/lafzî beyana yönelik birçok farklı tanım yapmışlardır. (Bk. Câhiz, 2018, c. 1, ss. 56-57, 105) Bu tanımlardan biri şöyledir: Kullanılan isim; anlatılmak istenen manayı kapsamalı ve maksadı tam olarak ifade etmeli, ikinci bir manaya taşmamalı, yapmacıklık ve zorlamadan uzak olup, anlaşılması için düşünmeye ihtiyaç bırakmamalı ve mananın çetrefilli olması/ta‘kîd ile yorum/tevilden uzak olmalıdır. (Câhiz, 2018, c. 1, s. 56)

\section{Söz ile beyan}

Câhiz, susmanın övülüp, konuşmanın yerildiği bazı rivayetleri hadis-i şeriflerden, sahabe ile tabiin sözlerinden ve Arap kelamından aktardıktan sonra bu rivayetlerin sebebi vürûdunun doğru anlaşılmadığını, bu yüzden bu rivayetlerin yanlış anlaşıldığını ve yorumlandığını ifade ettikten sonra bu yanlış anlaşlmalara itibar edilmemesi gerektiğini söyler. Ona göre bir kimse, eğer güzel konuşma yeteneği varsa, cahillerin korkutmalarına sakındırmalarına kanmayıp bu yeteneğini ihmal etmemeli, topluluk içerisinde yeteneğine uygun davranmalı ve en güzel şekilde sözlü beyanlarda bulunmalıdır. $\mathrm{Bu}$ konuda Allah Teâlâ'nın "Biz Davud'un mülkünü güçlendirdik, ona hikmet ve hakla batılı ayıran söz (hüküm verme) yeteneği verdik" (Sâd 38/19) ayetini, Hz. Peygamber'in "Şuayb (a.s.) peygamberlerin hatibidir" sözünü delil getiren Câhiz, muhataplarına şöyle seslenir; "Davud (a.s.) güzel konuşmada önderin ve Şuayp (a.s.) da imamın iken hatiplerden/güzel konuşanlardan olmaktan nasıl korkarsın”. Söz ile beyanın gerekliliğine deliller sıralamaya devam eden Câhiz, Hz. Peygamber'in ve Hülefâ-i Raşidin'in konuşmalarını, Hz. Peygamber'i düşmanlarına karşı savunan şairlerini ve Hz. Peygamber’in hatibi Sabit b. Kays’ı örnek verir. Ona göre, konuşma yerilen bir şey olsaydı bu durumda en çok yerilmesi gerekenler Hz. Ali ve Abdullah b. Abbas olurdu çünkü onlardan birçok konuşma ve söz rivayet edilmiştir. (Câhiz, 2018, c. 1, ss. 126-127, 166-167) Nitekim yeteneklerine uygun olarak doğal bir şekilde hitapta bulunan, kendini kontrol eden ve takva sahibi beyân ehlinin insanların arasını düzeltmek ya da yakılan 
bir fitne ateşini söndürmek için yaptıkları konuşmalarda, bir nikâh akdinde veya bir minber üzerinde cemaate sohbetlerinde tekellüf² ${ }^{2}$, fazlalık ve saçmalama/gevezelik olmaz. (Câhiz, 2018, c. 1, s. 127)

\section{Belâgat}

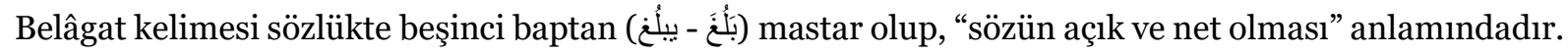
(el-Cevherî, 1987, c. IV, s. 316; İbn Manzûr, 1990, c. VIII, 419-421). Bu kelimenin, "sözün anlam açısından olgunluğa erişmesi" anlamında birinci babtan "bülûğ" kökünden olduğu iddia edilmişse de (Cürcânî, 1997, s. 25, Asım Efendi, 2013, c. 4, s. 3576) bu uygun düşmemektedir. Çünkü "bülûğ" kelimesi ile hem bab hem de sığa açısından farklıdır. (Kılıç, 1992, s. 380) Istılahta, "sözün açık ve seçik olmasının yanında yer ve zamana da uygun olmasıdır" (Kazvînî, ty., s. 9; Meydan, 2020, ss. 60-61) şeklinde tarif edilen belâgat için bu tanımın yapılması hayli uzun bir dönem sonunda gerçekleşmiştir. Çünkü belâgat uzun süre edebi zevkin ürünü olan bir meleke olarak varlığını sürdürmüştür.

Belâgatın sadece Araplara mahsus olmadığını söylemeliyiz. Nitekim "Fârisi bir kişiye belâgat nedir diye sorulduğunda, 'fasıl ile vaslı birbirinden ayırabilme kabiliyetidir', demiş. Belâgat nedir? sorusuna Yunanlı, 'meseleleri düzgün biçimde taksim edip, doğru lafızları seçmektir', cevabını vermiş. Rum'a belâgat nedir? diye sorulduğunda, 'söze iyi ve güzel bir başlangıç yapmak, sözün uzatılması halinde mâna ve lafızların zengin olması demektir', cevabını vermiş. Hintli'ye belâgat nedir diye sorulmuş, 'delâletin açık olması, sözün düzgün olup, yerinde ve zamanında söylenmesidir', diye cevap vermiş." (Câhiz, 2018, c. 1, s. 63) Bu ifadeler bize belâgat düşüncesinin ve onun üzerinde düşünmenin edebiyatı olan tüm milletlere özgü bir şey olduğunu anlatmaktadır.

\subsection{Araplarda belâgat}

Araplarda belâgatın onların tarihi kadar eskiye dayandığı kabul edilse de bize intikal eden ilk örneklerinin cahiliye şiirinde olduğunu söyleyebiliriz. Ancak cahiliye şiirinde bunun yazılı kurallara tabi bir ilim olmaktan ziyade edebi zevke dayanan, sözlü geleneği olan edebi tenkit içinde vücut bulduğunu söylemeliyiz. Zira bu dönemde bir meleke olarak edebi eleştiri anlamına gelen belâgat; bir anlamın ve bir düşüncenin farklı ifadeleri, kelime seçimleri, ifadelerin çetrefilli/ta'kid olmaktan uzak olması, îcâza riayet edilmesi ile kelamın muktezaya uygunluğu (Atik, 2005, ss. 11-12) ve söz-mana ilişkisi (Câhiz, 2018, c. 1, ss. 73, 76, 78, 157-158) üzerinden edebi zevke dayanarak yapılıyordu.

Ayrıca cahiliye döneminde belâgat, o dönem insanlarından belli bir zümreye özgü olmayıp tüm fertlerin ifadelerinde uygulamaya yansımaktaydı. Çünkü onlar için belâgat fitrat ve selikalarının bir gereği olup, gönüllerinin âşık olduğu, dillerinin ve kulaklarının alıştığı ve hoşlandığı bir durumdu. Arapların erken dönemlerden itibaren dile ait kusurları bildikleri bir gerçektir. Ancak bu dönemde beliğ bir kelamın özellikleri bu özelliklerin isimleri koyulmadan, ıstılahlar oluşmadan Arapların kelamında -şiir ve hitabelerinde- bulunmaktaydı. (Mübarek, 2001, ss. 21, 24, 28-31)

\subsection{Meleke olarak belâgat (edebi zevk)}

Araplarda bir meleke olarak belâgat yeteneğinin varlı̆̆ının en açık göstergesi, Kur'an-ı Kerim’in onlara bir benzerini getirmeleri konusundaki meydan okuyuşu, 3 onların da buna karşllı verme çabalarına rağmen sonuca ulaşamamış olmalarıdır. Bu durum o günün Arap toplumuna indirilmiş olan Kur'an'ın belâgat özelliklerinin Kur'an seviyesinde olmasa da Araplarda var olduğunun bir göstergesidir. Hz. Peygamber’in sözlerinde de Araplarda belâgat yeteneğinin varlı̆̆ına işaretler vardır. Nitekim onun " إن

Tekkelüf ün farklı anlamları için bkz. Öznurhan, 2005, ss. 180-183; Güler, 2011, ss. 73-76.

Bk. el-Bakara, 2/23; Hûd 11/13; el-Kasas 28/49; et-Tûr 52/34 Adres Address 
"من البيان لسحر ا" (Şüphesiz beyanda bir büyü vardır)4 sözü de beyanın, kelamın etkileyici yönünün o toplum açısından bilinen ve takdir edilen bir durum olduğunu göstermektedir.5

Ukaz panayırında her yıl düzenlenen şiir ve edebiyata dair yarışmalarda şairler sanat dolu eserlerini ortaya koyarlar ve bu eserler Kureyş’in fesâhat ve belâgat alanında temayüz etmiş olan şair ve edebiyatçlarının beğenisine sunulurdu. Bu eserlerden benzerlerine üstün gelenler takdir edilir ve ödül olarak Kâbe duvarına asılırdı. İlk olarak şiiri Kâbe duvarına asılan, belâgattaki üstünlügüule nam yapmış olan İmruu'l-Kays'dır. (Mehmed Kâmil, 1888, ss. 5-6)

Bu panayırda Nâbiğa ez-Zübyânî (ö. 604) için kırmızı bir çadır kurulur, burada onun hakemliğine başvurulurdu. Şairler gelip huzurunda şiirlerini okurlar Nâbiğa bu şiirleri değerlendirirdi. Onun galip ilan ettiği şairin ünü her tarafa yayılır ve diğer şairlere karşı bir üstünlük sağlardı. (Atîk, 2005, s. 10) Onun bu hakemliklerinde A'şâ’yı Hassan b. Sâbit'e, Hansâ'yı da diğer şairlere üstün tutması üzerine Hassân b. Sabit'in kendisine çıkışıp "ben hem senden hem de Hansâ'dan daha üstün bir şairim” demesi üzerine Nâbiğa'nın ondan şiir okumasını istediği ve onun okuduğu şiiri dil ve edebiyat açısından tenkide tabi tuttuğu kaynaklarda zikredilmektedir. (Dayf, ty., s. 11) Bu rivayetler Nâbiga'nın şiirlerin manası ve üslubu ile ilgili bazı kriterleri göz önünde bulundurduğunun bir delilidir. Yine bu dönemde İmruu'lKays'ın karısı Ummu Cundub'ün, 'Alkametu'l-Fahl ile kocası arasında geçen bir münazarada hakemlik yapması (İbn Kuteybe, 1982, c. 1, ss. 212-213) da o dönemde şiir ve edebiyatta birtakım değerlendirme kriterlerinin olduğunu göstermektedir. Bazı şairlerin belli konularda çok iyi şiirler söylüyor olmaları, mesela deveyi en iyi betimleyenin Uyeyne b. Mirdâs, (Asmaî, 1980, s. 18) atları en güzel betimleyeninse Tufeyl, buna mukabil Nâbiga, Züheyr ve Evs'in atları güzel betimleyemediklerinin ifade edilmesi edebiyat inceleme ve eleştirilerinin daha çok anlam ve edebi zevk üzerinden olduğunu göstermektedir. Hatta buna bir başka örnek de Hz. Muaviye'nin Tufeyl el-Ğanavi’nin şiirlerinin, daha eski şairlerin şiirlerine Züheyr b. Ebi Sülmâ’nın şiirlerinden daha çok benzediğini söylemesidir (Asmaî, 1980, s. 10)

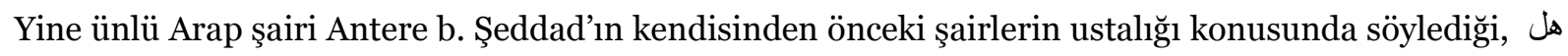
غادر الثعر اء من متردم (Şairler onarılması gereken bir (eksiklik) bıraktılar mı?) şiiri o dönem bir edebi eleştirinin olduğunu ifade etmektedir.(Atik, 2005, s.11) O halde Arap edebiyatında cahiliye çağından başlayarak dil ve edebiyat eleştirisinin varlığı ve bunun yazılı olmasa da bazı kriterlere bağlı olduğu bir hakikattir. Çünkü insanların kendisi ile övüldüğü veya yerildiği sözler tabaka tabakadır. Dolayısıyla insanların sözlerinin eşit olup, birbirine üstünlüğünün olmadığı veya aralarında farklıllğın olmadığı iddia edilemez. Aksi halde, kimi sözlerin sağlam, hafif ve güzel; kiminin de düşük, ağır ve çirkin olarak nitelenmesinin bir anlamı olmazdı. (Câhiz, 2018, c. 1, s. 95)

Cahiliye toplumunun "Kur'ân-ı Kerim'in Allah kelamı olduğuna iman çağrısına" cevap verebilmeleri ve bu çağrının anlamlı olabilmesi için onların beşer kelamı ile Allah kelamını birbirinden ayırt edebilecek bir ölçüte/melekeye sahip olmaları gerekmekteydi. Bu ölçüt, nesiller boyu aktarılan, tevarüs eden bir bilginin ve zevkin sonunda elde edilebilecek bir his, bir anlayış olup bu his ve anlayış Câhiliye Araplarında yerleşik olan belâgat yeteneği bir başka deyişle “edebî zevk”tir. (Tülü, 2016, s. 226).

\subsection{Meleke olarak belâgatta değerlendirme usulleri}

Cahiliye döneminde yazılı bir edebiyat geleneği söz konusu olmadığı için yazılı bir tenkit geleneğinden de söz edilemez. Ancak panayırlarda düzenlenen şiir ve edebiyat yarışmalarındaki değerlendirmelerden ve daha o dönemde şairlerin muallaka şairleri ve diğer şairler olmak üzere gruplandırılması hatta muallaka şairlerinin de kendi aralarında derecelendirilmesi bu dönemde sözlü değerlendirme

Buharî, Sahih, Kitabu't-Tip, 5767

Hz. Peygamber ve bu sözü kendisine hitaben söylediği Amr b. El-Ehtem arasındaki dialog için bkz. Cahız, Ebu Osman Amr b. Bahr, el-Beyan ve't-Tebyin, tah. Derviş Cüveydi, I-III, Sayda, el-Mektebetü’l-Asriyye, 2018, c. I, s. 43 Adres Address 
kriterlerinin varlı̆̆ını ortaya koymaktadır. Daha sonraları ortaya çıkan ve belâgat ilminin ilk kaynakları arasında gösterilen yazılı tenkit (edebî eleştiri) eserlerinden öğrendiğimize göre bu dönemde edebi metinler; kelime tahlilleri, kelimelerin birbiri ile uyumu, biçim/form, mana ve teşbih sanatı üzerinden değerlendiriliyordu. Bu dönemde eleştiri noktaları uzun uzun ta‘lil edilerek sebepler sıralanmıyor, aksine daha toplu ve genel ifadelerle edebi tenkit noktaları ifade ediliyordu. (İbn Reşik el-Kayrevanî, 1981, c. 1, ss. 94-98; Mübarek, 2001, s.30) Müberred kendisine "şiir mi düz yazı mı daha beliğdir" şeklinde yöneltilen bir soruya şöyle cevap vermiştir "Belâgatın hakkı; sözün seçkin olması, manayı kuşatması ve güzel bir nazım/diziliştir. Bu da kelimelerin birbiriyle uyumlu olmasıyla, şeklen birbirini desteklemesiyle, uzak manaların bu kelimelerle yakınlaşmasıyla ve fazlalıkların atılması ile olur." (Müberred, 1985, s. 81) Müberred'in ifadelerinden de anlaşllacă̆ üzere ilk dönem değerlendirmeler yukarıda da belirtildiği gibi genel bir bakış açısıyla, kelime seçimi, kelimeler arası uyum, dizim ve sözün kastedilen manayı ifade etmesi açısındandır. Bakıllanî de İmruu'l-Kays'ın muallakasını ve Buhturî'nin kendi ifadesiyle en iyi şiirini; mana, lafız, istiare bakımından edebi bir eleştiriye tabi tutmuştur. (Bâkıllânî, 1997, ss. 159-183, 219-241) O, bu şiirleri meleke olarak kendisinde var olan belâgat anlayışına ve edebi zevke göre değerlendirirken belağatın müstakil bir ilme dönüşmesinin öncülerinden oluyordu.

Diğer taraftan belâgatın müstakil bir ilme dönüşmesinden sonra kısımlarından biri olan meânî ilminin ve Abdülkahir Cürcânînin nazm teorisinin temellerini oluşturan (Dayf, 1994, s.103) nahiv ilminin insanların yapmış oldukları dil hataları üzerine ortaya çıkışını konu alan rivayetler de (Dayf, 2005, ss. 13-16) o dönemde yazılı olmasa da bir edebî eleştirinin varlığını göstermektedir. Nitekim nahvin öğrenilmesi ilk dönemlerden itibaren teşvik edilmiştir. Hz. Ömer'de şöyle demiştir; "Sünnetleri ve farzları öğrendiğiniz gibi nahvi de öğreniniz". Eyyüp Sehtiyâni de şöyle der; "Nahvi öğreniniz. Zira nahiv alt seviyedeki için bir güzellik; onu bilmemek ise soylu, ileri gelen kimseler için bir ayıptır”. (Câhiz, 2018, c.2, s. 337)

\section{a- Şairin kendini değerlendirmesi}

İlk edebî eleştirmenler yine şairlerin kendileriydi. Zira bazı şairler şiirlerini tam bir yll bekletip üzerinde inceleme, tenkit ve düzeltmeler yapıyor sonra toplum önünde bu şiiri îrad ediyordu. Bu şiirlere "havliyyât, mukalledât, munekkehât ve muhekkemât" denir. (Câhiz, 2018, c. 2, s. 241) Züheyr b. Ebî Sülmâ' da, şiirlerini yazdıktan sonra bizzat kendisi edebi eleştiriye tabi tutup "havliyyât" yazan şairlerdendir. (Dayf, 1994, s.103) Yine şairlerin kendilerini eleştirdiğini bir başka açıdan gösteren örnek; Züheyr b. Ebî Sülmâ’nın ما أر انا نقول إلامعارا أو معادا من لفظنا مكرورا "Kendimizi, sadece eğreti alınmış ya da

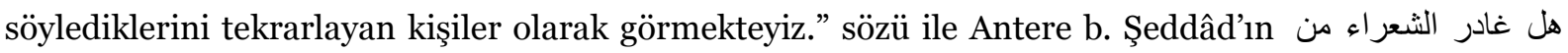
(Şairler onarılması gereken bir (eksiklik) bıraktılar mı? ) şeklindeki şiiridir. $\mathrm{Bu}$ sözler zikri geçen şairlerin kendilerini şiir ve edebiyat konusunda eleştirdiklerini göstermektedir. (Atîk, 2005, s. 11)

\section{b. Şairin başka şairleri değerlendirmesi}

Şairlerin başka şairlerin şiirlerini, lafiz özelliklerine, mana özelliklerine göre değerlendirmeye tabi tuttukları gibi lafızların birbiriyle uyumu, lafız mana uyumu ve metnin genelindeki anlam bütünlüğü açısından da değerlendirmekte idiler. Burada ilgili eleştiri usullerine yer verilecektir.

\section{Lafzın özellikleri bakımından}

Câhiz, Ebu Amr eş-Şeybânî’nin bir şiir değerlendirmesinde "manaların güzelliği"ni öne çıkarmasını eleştirirken şiirde ifade edilmek istenilen manaların Arap-acem; bedevi, köylü, şehirli herkes tarafından bilinen düşünceler olduğunu, şiiri kaliteli yapan özelliklerin kelime seçimi, kelimeler arası uyum, zoraki sanat yapmadan doğal bir tarzda şiiri söylemek olduğunu söylemektedir. (Câhiz, 2003, c. 3, s. 67) Bu 
değerlendirmelerden de anlaşllacağı üzere sadece yüce manalar ifade edilmesi bir kelamı belîğ yapmamaktadır. Yukarıda da değinilen, İmruu'l-Kays'ın karısı Ummu Cundub'ün, 'Alkametu'l-Fahl ile kocası arasında geçen münazaradaki hakemliği yerine getirirken 'Alkame'nin kelime seçimi, teşbih ve tasvirde üstünlüğünü gerekçe göstererek kocası aleyhinde hüküm vermesi de lafız bakımından yapılan edebî tenkitin bir başka örneğidir. (İbn Kuteybe, 1982, c. 1, ss. 212-213) Nitekim ilk dönemden itibaren iyi bir şiirin nitelikleri açıklanırken kelimelerinin, çarşı pazarda halk arasında kullanılan sûki/çarı pazarda kullanılan, düşük ve avamî kelimeler olmaması şart koşulmuştur. Hatta bunlara ilaveten şiirin kelimelerinin garip ve vahşi/badiyelerde kullanılan kelimeler olmaması da gerekli görülmüştür. Sadece muhatap kitle bedevilerden oluşan bir topluluk ise bu durumda kelimeler vahşi olabilir. (Câhiz, 2018, c. 1, s. 95) Belâgatta kelimenin fasih olması için şart koşulan vahşi, müstekreh/hoş görülmeyen, garip/az bilinen olmayacak şartları Kur’an-ı Kerim'in i'caz ve belâgatı anlatılırken de gündeme gelmiş ve Kur'an1 Kerim'in kelimelerinin bu şartlara uygunluğu i‘câzının sebepleri arasında gösterilmiştir. (Bâkıllânî, 1997 , ss. 46, 180)

Belâgatta lafzın önemini anlatan ifadelerden biri de şu rivayettir; "Bir hakîme "Belâgatı bir araya getiren şey" nedir diye sorulduğunda hakîm, "illetli lafızlarla salim lafızları bilmek, mutlak lafız ile içerisinde farklı anlamları barındıranı ayırt edebilmek, müşterek ile müfred lafız farkını bilmek ve mukayyed metinlerden manası te'vile ihtimali olanları ayırt edebilmektir." diye cevap vermiştir. (Câhiz, 2018, c. 1, s. 283)

\section{Lafizların birbiriyle uyumu bakımından}

İlk dönem edebî eleştiri ve belâgatın değerlendirme ölçütlerinden biri yukarıda da zikredildiği gibi lafızların birbiriyle uyumlu ve ahenkli olmasıdır. Nitekim bu konu daha sonraları belâgatta "tenâfurü'lkelimât” başlığı altında incelenecektir. Lafızların birbiriyle uyumu konusunda Câhiz, Halef el-Ahmer'in (v. 180/796) "Beytin bir lafzı diğer lafizlara uygun olacak, uyum arz edecek tarzda bir yere koyulmazsa lafizlar arasında uyuşmazlık oluşur ve şïrin söylenişinde zorlanılır." şeklindeki görüşlerini aktardıktan sonra kaliteli şiir ile ilgili şu düşünceleri ifade etmektedir:

"En kaliteli şiir, parçaları birbirine âdeta yapışmışçasına uyumlu ve harflerinin dilden dökülüşünün kolay olduğunu gördüğün şiirdir. Bu durumda sen bu şiirin bir defada dile getirilmiş ve tek seferde bir kalıba dökülmüş olduğunu anlarsın. Bu şiir dil üzerinde yağın aktığı gibi akar”. (Câhiz, 2018, c. 1, ss. 75-76)

"Telâum” olarak isimlendirilen bu kavramı Bâkıllânî şöyle açıklar; "Telâum, kelimeler arasında tenafürün olmaması, lafızların kolay telaffuz edilebilmesi, mananın kalbe tesir etmesidir. (Bâkıllânî, 1997, ss. 269-270) Abdülkâhir el-Cürcânî̀nin belâgat alanında ortaya koyduğu görüşlerinin "nazm teorisi” olarak ele alınması da sözcüklerin ve söz öbeklerinin birbiriyle uyumunu belâgatın merkezine yerleştirdiğini göstermesi bakımından önemlidir.

\section{Lafiz mana uyumu bakımından}

Bir kelamın belâgata uygun kabul edilmesindeki ölçütlerden biri de söz ile, anlatılmak istenilen mananın birbiriyle uyumlu olmasıdır. Yani lafiz-mana arasında uyum olması ve lafızla-mananın aynı zamanda muhataba ulaşmasıdır. (Bâkıllânî, 1997, ss. 46, 180) Diğer bir ifade ile yukarıda el-Müberred'den nakille ifade edildiği üzere "kelam manayı kuşatmalıdır”. Eğer kelamı süslemek adına mana ihmal ediliyorsa bu eleştiri konusu olmuştur. Nitekim bir bedîi sanat olan seci‘ bu açıdan değerlendirilmiş, kimi belâgatçılar bu sanatta mana lafza tabi k kılındığı için bunu hoş görmemişlerdir. Hatta bu bağlamda Kur’an-ı Kerim'de seci“ olup olmadı̆̆ı tartışılmış âlimlerin bir kısmı "seciił" lafzi güzellik ve uyum için ifade edilmek istenen manayı sınırlayan bir sanat olarak gördükleri/tanımladıkları için Kur'an-ı Kerim'de var olan ayet sonlarındaki uyuma seci' değil "fevasıl” /fâsıla demişlerdir. Bâkıllâni böyle düşünmekte ve bu konuda 
şöyle demektedir; "Fevasıl, "makta”larda (nesir/düz yazı tarzı metinlerde bölüm sonları) şeklen benzer kelimelerin bulunmasıdır. Bu kelimeler sanat yapma amacı gütmeyip manayı ifade etmek için getirilirler. Fevasıl, seci'den farklıdır. Çünkü seci'de mana, bu sanata tabi olup onu takip eder, yani seci‘ yapmak için mana feda edilebilir. Fevâsılda durum böyle değildir. Çünkü orada fevasıl manaya tabidir. (Bâkıllânî, 1997, s. 270). Buna mukabil bazı alimler seci‘ sanatını böyle değerlendirmemişlerdir. Onlara göre mühim olan seci‘in, lafız mana uyumuna zarar verip vermediğidir. Bu uyuma zarar vermediğinde seci‘i belâgi bir özellik taşır. O halde bu görüş sahipleri, mühim olanın seci‘ için tekellüfte bulunulmaması, anlamın bozulmaması ve seciin manaların kıymetli olduğu hissini vermeye aracı kılınmaması olduğunu ifade etmişlerdir. (Câhiz, 2018, c. 1, ss. 176-178) Bazı alimler bu konuda bir adım ileri giderek seci‘ sanatının Arap kelamının bir özelliği olduğunu ve Kur’an-ı Kerim’in Arap kelamının söyleyiş biçimlerine uygun geldiği için Kur'an'da seci‘ var olduğunu söylemişlerdir. (bk. Tehânevî, 1996, c. 1, s. 932)

Lafız mana uyumunda dikkat edilen ve eleştirilen hususlardan biri de söylenen manaların kıymetli, önemli olduğu hissini vermek için avurtları şişirerek konuşma, zorlama sanatlar yapma ve boş gereksiz laf kalabalığı yapmaktır. (Bâkıllânî, 1997, ss. 46, 180) Hz. Peygamber (s.a.v.) de avurtlarını şişirerek konuşanları ve zorlama sanat yaparak insanları etkilemeye çalışanları kınamıştır. (Ebû Davud, 2009, c. 7, s. 353-354) Kur'ân-ı Kerim’in şairleri yerdiği ayeti yorumlayan Cahiz, sanat için tekellüfte bulunmalarını ve övünmeye çabalamalarını onların yerilme sebeplerinin içerisinde zikretmiştir. (Câhiz, 2018, c. 3, s. 607) Belâgatta lafız-mana uyumunun ehemmiyetini en güzel ifade eden Câhiz'dır. Ona göre bir kelamın beliğ olabilmesi lafız ile mananın birbiriyle yarışmasıdır. Lafız kulağa dokunmadan önce mana kalbe varmadıkça bir söz beliğ vasfını alamaz. (Câhiz, c. 1, s. 78 )

\section{Mana eleştirisi}

Yukarıda da Asmaî’den naklen belirtildiği gibi bazı şairlerin belli konulardaki tasvirlerinin ve şiirlerinin daha iyi bulunması edebi metinlerin mana üzerinden değerlendirildiğinin bir göstergesidir. (bk. Asmaî, 1980, ss. 10-18) Mana üzerinden yapılan eleştiriler ayrıca kullanılan imgeler, imgelerin abartılması ve semboller üzerinden de yapılmaktadır. İlk dönem Araplarında ve farklı kültürlerden etkilenmeyenlerde tekellüf, hoş görülmeyen sözler ve çok garip manalar/az bilinen manalar, aşırı imgeler yoktur. Fakat müvelledlerde, şehirlerde farklı kültürlerle karşılaşan kimselerde ve iyi bir edîp gözükmek için çabalayanlarda bu özellikler görülür. (Câhiz, 2018, c. 2, s. 241; Câhiz, 2003, c. 3, s. 67)

Cahız’a göre Hz. Peygamber’in "güzel sözlerle aldatma yoktur" sözünden maksat çarşı pazarda halk arasında kullanılan sûki, düşük ve avamî kelimelerden ve dolambaçlı söylemekten kaçınmayı, gayreti lafızları güzelleştirme ve garip manalar elde etmeye harcamamayı tavsiye vardır. (Câhiz, 2018, c. 2, ss. 157-158)

\section{Belâgata dair bir metnin/hitabın bölümler arasında mana ilişkisi}

İlk dönem değerlendirme ölçütlerinden biri de metnin/hitabın bölümleri arasında mana uyumu ve bütünlüğünün olmasıdır. Nitekim her bir mısra ve beyit kendi içinde çok güzel anlamlara sahip olsa da eğer bir bütünlük arz etmiyorlarsa bu belî̆g bir metin olarak değerlendirilemez. ${ }^{6}$ Hatta bir şiirin tüm beyit ve mısraları deyim ve atasözlerinden oluşsa fakat aralarında mana açısından bir uyum bulunmasa bu şiir çok değerli olmaz. Zira dinleyici her beyitte meselin verdiği anlamla diğer beyit arasında bir anlam ilişkisi kuramazsa bu söz diziminin bir anlamı olmaz. Övgüyü hak eden iyi ve güzel şiirlerde beyitler arasında mutlaka bir konu bütünlügü vardır, olmalıdır. (Câhiz, 2018, c. 1, s. 129) İbni Tabâtabâ da en güzel ve en kaliteli şiirin özelliklerinden birinin de bölümleri arasında mana uyumunun bulunması

Mesellerden oluşturulan beyitlerin şiir formuna dönüşmesi için beyte dâhil edilen lafiz ve cümle örnekleri için bkz. Hâtimî, A., (1979), Hzlyetü'l-muhadara, tah. Ca'fer el-Kenani. y.y., Daru'l-hürriyyet, ss. 61-70 Adres Address

Kurklareli Üniversitesi, Fen Edebiyat Fakültesi, Türk Dili ve Edebiyatı Bölümü, Kayalı Kampüsü-Kırklareli/TÜRKIYYE

Kırklareli University, Faculty of Arts and Sciences, Department of e-posta: editor@rumelide.com $\quad \begin{aligned} & \text { e-mail: editor@rumelide.com } \\ & \text { e-cur }\end{aligned}$ 
olduğunu söylemektedir. Ona göre şiir, her biri başlı başına müstakil olan hikmetli sözlerden veya yaygın, bilinen darb-ı mesellerden oluşturulsa bile bunlar arasında şiirin söylenmesinden maksat olan manayı anlatmak hususunda bir uyum yoksa bu şiir iyi bir şiir olamaz. Şiirin bölümleri arasındaki geçişler, şiir âdeta tek seferde söylenmiş gibi bir tarzda olmalıdır. İyi bir şiirin manaları arasında çelişki, yapısında zayıflık ve söz diziminde tekellüf/zorlama olmamalıdır. Şiirdeki her bir kelime ifade edilmek istenilen manaya uygun, bir önceki kelimeyle uyumlu ve kastedilen mananın tamamlanması için bir sonraki kelimeye de muhtaç olmalıdır. (İbn Tabâtabâ, 2005, ss. 131-32; Tülü, 2017, ss. 127-128) Kudâme b. Cafer (337/948) ise şiirin bölümlerinin manaları arasındaki uyum için "sıhhatü't-taksim” (anlatılmak istenen mananın şiirin bölümlerine ölçülü bir şekilde ayrılması ve bu bölümler arasında uyum bulunması) ifadesini kullanır (Ebu'l-Ferec, t.y., 139-141; Tülü, 2017, s. 128) . "Sıhhatü't-taksim"de şairin dikkat etmesi gereken durum, şiirde anlatmak istediği manayı bir bütün halinde görüp bu bütünü doğru bir şekilde şiirin bölümlerine paylaştırması ve bölümler arasında bu bütünlüğü bozacak bir uyumsuzluğa meydan vermemesidir.

Kudâme b. Cafer yukarıda naklettiğimiz durumlara riayet edilmemesini ise şiirin ayıplarından (fesadu'ttaksim vb.) saymakta ve her bir durum için yine kadim şiirden örnekler vermektedir. (Ebu'l-Ferec, t.y., 192-195; Tülü, 2017, s. 129)7

\section{Sonuç}

İslâmî ilimler içinde bağımsızlı̆̆ını en son elde eden ilimlerden biri de belâgat ilmidir. Ancak bir meleke olarak belâgatın tarihi insanlık tarihiyle başlar. Araplarda belâgat, bu milletin tarihiyle başlamakla birlikte belâgata kaynaklık eden ilk metinler cahiliye dönemindeki edebi ürünler; ağırlıklı olarak cahiliye şiirleridir. Cahiliye şiirleri üzerinden Araplardaki edebi zevk ve melekenin tespiti ise bu şiirlere dair ortaya konan edebi eleştirilerde kendini göstermektedir. Dolayısıyla bir meleke olarak belâgat, bu ilmin temel dayanaklarından biri olan edebi eleştiri ile büyük oranda ortaktır.

Arap edebiyatının inceliklerini onlardaki belâgat melekesini, bir başka ifadeyle edebi zevki ortaya koymayı hedefleyen edebi eleştiri ise sözlü ve yazılı olmak üzere iki döneme ayrılır. Cahiliye döneminden başlayarak İslam'ın ilk dönemlerinde yazılı gelenek söz konusu olmadığından genellikle şair ve ediplerin sözlü değerlendirmeleri bu alanda kaliteli ürünlerin ortaya çıkmasına katkı sağlamıştır. 2/7. asırdan itibaren ilimlerin yazılı hale dönüşmesiyle birlikte bu dönemdeki sözlü tenkit rivayet yoluyla kitaplara aktarılmış, ayrıca geçmiş dönemdeki edebi ürünlerden faydalanılarak edebi tenkidin yazılı kuralları oluşturulmuştur.

Gerek cahiliye ve İslam'ın ilk dönemlerinden intikal eden rivayetler gerekse belâgatın temel dayanaklarından olan edebi tenkide dair yazılı ilk metinlerden elde edilen veriler ışığında meleke olarak belâgatın bir takım değerlendirme usulleri vardır. Bu değerlendirme usulleri içinde hem şairlerin kendilerini kritik etmesi hem de bu konuda görüşlerine değer verilen tenkitçi şairlerin başkalarını değerlendirmeleri söz konusudur. Bu dönemde ortaya konulan edebi metinler; kullanılan lafizların özellikleri, lafızların birbiriyle uyumu, lafızların ifade edilmek istenen mana ile uyumu açısından değerlendirmeye tabi tutulmalarına ek olarak manaların özellikleri bakımından da değerlendirilmiştir. Mısra ve beyitlerde de manaların uyumlu olmasına önem verilen bu değerlendirmelerde, manaların; tekellüf/zorlama, ta'kîd/mananın çetrefilli olması gibi kusurlardan uzak olması, sanat yapma kaygısıyla aşırı imge ve abartılardan kaçınılması gibi hususlar, üzerinde durulan önemli noktalardır.

\footnotetext{
Kudâme b. Cafer, a.g.e., s. 192-195. 


\section{Kaynakça}

Afgânî, S. (1974). Esvâku'l-‘Arab fi câhliyyeti'l-İslâm. (3. bs.). Beyrut: Dâru'l-fikr.

Arslan, H. (2019). Kadim iki belâgat eserinin mukayesesi: Miftâhu'l-'Ulûm ve Telhîsu'l-Miftâh. RumeliDE Dil ve Edebiyat Araştırmaları Dergisi, (17), 596-611.

Asım Efendi. (2013). el-Okyânûsu'l-basît fi Tercemeti'l-Kâmûsi'l-Muhît. Yay. Koç, M., Tanrıverdi, E. (Cilt 1-9) İstanbul: Türkiye Yazma Eserler Kurumu Başkanlığı.

Atik, Abdülaziz. (2005). fi Târîhi'l-Belâgatil-Arabiyye, Beyrut: Dâru'n-nahdati'l-Arabiyye.

Bâkıllânî, M. (1997). İcâzu’l-Kur'ân. (5. bs.). tah. Seyyid Ahmed Sakr. Mısır: Dâru'l-meârif.

Câhız, A. (2003). el-Hayevân. (2. bs.). (Cilt 1-7). Beyrut: Daru'l-kütübi'l-ilmiyye.

Câhız, A. (2018). el-Beyân ve’t-tebyîn. tah. Derviş Cüveydî. Beyrut: Şirketü ebnâi şerîfi'l-ensâr.

Cürcânî, A. (1997). Kitâbu't-Ta'rifat. Beyrut: Mektebetü Lübnan.

Çetin, Nihad M. (2011). Eski Arap Şiiri. (2. bs.). İstanbul: Kapı yayınları.

Dayf, Ş. (1994). en-Nakd. (5. bs.). Kahire: Dâru'l-Maarif.

Dayf, Ş. (2005). el-Medârisü’n-nahviyye. Kahire: Dâru'l-Maarif.

Dayf, Ş. (t.y.). el-'Asru'l-câhilî. (11. bs.). Kahire: Dâru'l-Maarif.

Ebû Davud, S. (2009). Sünen. tah. Şuayb Arnavut. (Cilt 1-7). Beyrut: Dâru'r-risâleti'l-‘âlemiyye.

Ebu'l-Ferec, Kudâme b. Cafer, (t.y.). Nakdu'ş-şír. tah. Muhammed Abdülmunim Hafacî. Beyrut: Daru'lkütübi'l-İlmiyye,

el-'Asmaî, A. (1980). Fuhûleti’ş-şu'arâ. Tah. Beyrut: Dâru'l-kitabi'l-cedid.

el-Cevherî, İ. (1987). Tâcü'l-lüga ve sıhâhu'l-Arabiyye. tah. Ahmed Abdülgafur Attâr. Beyrut: Dâru'lilm li'l-melâyîn

el-Merâğ̂̀, A. Mustafa. (1993). 'Ulûmü’l-belâga. (3. bs.) Beyrut: Dâru'l-kütübi'l-ilmiyye.

El-Müberred, M., (1985). el-Belâgat. (2. bs). tah. Ramadan Abduttevvâb. Kahire: Mektebetü'sSekâfetü'd-diniyye.

Güler, İ. (2011). İbn Kuteybe'nin Şiir Anlayışı ve Şaire Bakışı. Ankara Üniversitesi İlahiyat Fakültesi Dergisi [Ä̈IFF]. 52, 1, 69-78.

Güler, İsmail. (2011). İbn Kuteybe'nin Şiir Anlayışı ve Şaire Bakışı. Ankara Üniversitesi İlahiyat Fakültesi Dergisi [AÜIFD], LII, 1, 69-78. (Tekellüf tanımları için bkz. 73-74)

Hâtimî, A. (1979). Hzlyetü'l-muhadara, tah. Ca'fer el-Kenani. y.y.: Daru'l-hürriyyet.

Hüseyin, Muhammed H. (t.y.). Naḳdu kitâb fi’ş-Şi’ril'-câhilî. Kahire: el-Mektebetü'l-Ezheriyye li’tTürâs.

İbn Kuteybe, A. (1982). eş-Şi'ru ve'ş-şu'arâ. Kahire: Daru'l-Hadis.

İbn Kuteybe, A. (ty). Te’vilü Müşkili'l-Kur'an. tah. İbrahim Şemsuddin, Beyrut: Daru'l-kütübi'l-İlmiyye.

İbn Manzûr, (1990). Lisânü’l-Arab. Beyrut: Dâru's-Sâdır.

İbn Reşik el-Kayrevanî H. (1981). el-Umde fi mehasini’şşír ve âdâbih ve nakdih. tah. Muhammed Muhyiddin Abdülhamit. Kahire: Daru'l-cîl.

İbn Tabâtabâ, M. (2005). 'Iyâru'ş-şi'r. Beyrut: Daru'l-kütübi'l-ilmiyye.

Kâmil, M. (1888). Terceme-i Muallakât-ı Seb'a, İstanbul: Matbaa-i Osmaniye.

Kazvînî, Celâlüddin M. (t.y.). Telhisül-Miftah. İstanbul: Salâh Bilici Kitabevi.

Kılıç, Hulûsi. (1992). Belagat, DİA. V, 380-383

Meydan, A. (2020). Kutbüddîn-i Şîrâzî'nin İlimler Tasnifi ve Dil İlimlerinin Bu Tasnifteki Yeri. İhya Uluslararası İslâm İlimleri Araşttrmaları Dergisi, 6, 1, 41-69.

Muhammed, A. (1999). el-usûlül-belâgiyye fi kitabı Sibeveyhi ve eseruhafi'l-bahsi'l-belâgi, Kahire: Dâru'l-maarif. 
Mübarek, M. ( 2001). el-Mûcez fi tarihi'l-belâga, Beyrut: Daru'l-Fikr.

Özdemir, A. (2007). Eski Arap Şïrinin Zirve İsimlerinden Biri: Lebîd b. Rabîa el-Âmirî ve Divanu. Ankara: Araştırma Yayınları, s. 16;

Öznurhan, H. (2005). İbn Kuteybe'ye Göre Şiirde Yetenek Sorunu. Selçuk Üniversitesi İlahiyat Fakültesi Dergisi(SÜİFD), 19, 179-186.

Öznurhan, H. (2005). İbn Kuteybe'ye Göre Şiirde Yetenek Sorunu. Selçuk Üniversitesi İlahiyat Fakültesi Dergisi, 19, 179-186(Tekellüf tanımları için bkz. 180-183)

Râfiî,, Mustafa S. (1997). Târîhu âdâbi'l-'Arab. Kahire: Mektebetü'l-İman.

Şakir, Mahmud M. (2002). Medâhilü i‘câzi'l-Kur'ân. Kahire: Matbaatü’l-Medeni.

Şakir, Mahmud M. (t.y.). Kaḍiyyetü'ş-şi'ri'l-câhilî fi kitâbi İbn Sellâm. Kahire: Matbaatü'l-Medeni.

Tehânevî, M. Ali. (1996). Keşşâfu ıstılâhâti'l-fünûn ve'l-ulûm. tah. Ali Dahruc. (Cilt 1-2). Beyrut: Mektebetü Lübnan Naşirun.

Tülü, A. (2016). Mahmut Muhammed Şakir ve Câhiliye Şïri Hakkındaki Düşünceleri. (Yayımlanmamış doktora tezi). İstanbul Üniversitesi Sosyal Bilimler Enstitüsü, İstanbul.

Tülü, A. (2017). Kadim Arap Şiirinde Konu Birliği Meselesi. Usûl İslam Araşttrmaları. 27, 119-136. 